\title{
KOMPETENSI PENELITIAN TINDAKAN KELAS GURU SMP DIY
}

\author{
Sukidjo \\ Fakultas Ekonomi Universitas Negeri Yogyakarta \\ email: sukidjo_uny@yahoo.com
}

\begin{abstract}
Abstrak: Penelitian bertujuan untuk mendeskripsikan kompetensi guru SMP dalam Penelitian Tindakan Kelas (PTK). Subjek penelitian adalah para guru peserta kegiatan sosialisasi kurikulum 2013 oleh Direktorat Pendidikan Dasar dan Menengah Depdikbud di Yogyakarta. Subjek penelitian adalah 55 orang guru SMP dari Kabupaten Gunung Kidul dan Sleman. Penelitian menggunakan pendekatan survei. Pengumpulan data menggunakan kuesioner dan dokumentasi, sedang analisis data menggunakan teknik kualitatif dan kuantitatif. Analisis kualitatif berupa narasi, sedang analisis kuantitatif digunakan uji-t. Hasil penelitian menunjukkan bahwa guru SMP di DIY: (1) memiliki tingkat kompetensi PTK dalam kategori sedang khususnya tingkat penguasaan teoretik, kemampuan kognitif, dan kemampuan teknis: (2) tidak ada perbedaan tingkat kompetensi PTK antara guru golongan III dengan golongan IV: (3) guru yang pernah melakukan PTK memiliki kemampuan kognitif dan pengalaman yang berbeda dibandingkan guru yang belum pernah melakukan PTK; (4) tidak ada perbedaan penguasaan teoretis, kemampuan kognitif, kemampuan teknis yang disebabkan oleh masa kerja.
\end{abstract}

Kata Kunci : kompetensi, penelitian tindakan kelas, guru SMP

\section{JUNIOR HIGH SCHOOL TEACHERS' COMPETENCE IN CONDUCTING CLASSROOMACTIONRESEARCH}

\begin{abstract}
This study was aimed to describe the competence of junior high school teachers in conducting Classroom Action Research (CAR). The subjects were participants in the socialization of Curriculum2013 run by the Directorate of Primary and Secondary Education, Department of Education in Yogyakarta. The subjects were 55 junior high school teachers from Sleman and Gunung Kidul regencies. This study used the survey approach. The data were colllected using questionnaires and documentation. The data were analyzed using the qualitative and quantitative anlayses. The qualitative analysis was in the form of narrative, while the quantitative analysis used the t-test. The findings showed that: (1) the teachers' competence in conducting classroom action research belonged to the fair category, especially their theoretical mastery level, their cognitive ability, and their technical ability; (2) there was no significant difference in the competence in conducting classroom action research between the third rank teachers and the fourth rank teachers; (3) teachers who had conducted classroom action research had different cognitive competences and experience from those who had not conducted classroom action research; (4) there was no significant difference in the theoretical mastery, cognitive competence, and technical ability due to working experience.
\end{abstract}

Keywords: competence,Classroom Action Research

\section{PENDAHULUAN}

Salah satu faktor yang menentukan kemajuan suatu negara adalah kualitas sumber daya manusia (SDM). Manusia sebagai faktor produksi memiliki sejumlah potensi yang harus dikembangkan melalui pendidikan agar memiliki produktivitas yang optimal. Tersedianya SDM yang berkualitas merupakan modal yang sangat penting dalam pembangunan nasional.
SDM yang berkualitas akan mampu mengembangkan ilmu pengetahuan dan menciptakan teknologi yang sangat berguna untuk mengolah sumber daya alam guna meningkatkan pendapatan nasional dan kesejahteraan masyarakat. SDM yang berkualitas akan memiliki sikap entrepreneur yang tinggi sehingga dapat menghasilkan produk dan jasa yang optimal. Oleh sebab itu, kualitas SDM dapat dipandang 
sebagai salah satu kunci kemajuan suatu negara. Untuk meningkatkan kualitas SDM diperlukan pendidikan. Pembicaraan masalah pendidikan tidak akan lepas dari peran guru. Guru merupakan salah satu komponen yang sangat penting bahkan menentukan dalam proses mencerdaskan kehidupan bangsa. Bangsa yang cerdas adalah bangsa yang memiliki SDM yang berkualitas, SDM yang unggul, yang memiliki kemampuan dan keterampilan tinggi serta sikap yang positif. Guru memiliki posisi sentral dalam meningkatkan kualitas SDM.

Guru memegang peranan penting dalam pendidikan khususnya dalam pendidikan formal. Guru menentukan keberhasilan pendidikan melalui proses pembelajaran. Bahkan, guru dipandang sebagai komponen yang paling berpengaruh terhadap terciptanya proses dan hasil pendidikan yang berkualitas (Khotijah, 2013: 91). Mengingat sedemikian penting peran guru dalam meningkatkan SDM, guru dituntut untuk selalu meningkatkan kualitas kompetensinya sehingga benar-benar mampu sebagai guru yang profesional. Namun demikian, kualitas dan kompetensi guru di Indonesia belum sesuai dengan harapan.

Dilihat dari segi kualifikasi pendidikan, dari 2,92 juta guru yang berpendidikan S1 atau lebih baru $51 \%$ dan $49 \%$ belum berpendidikan S1 (Kompas, 7 Maret 2012). Kualitas pendidik yang belum menggembirakan diakui oleh Mendikbud dan dibuktikan dari hasil uji kompetensi awal yang nilainya rendah. Hasil uji kompetensi awal terhadap 281.016 guru TK hingga SMA/ SMK ternyata nilai rata-rata nasionalnya 42,25 , bahkan hasil uji kemampuan pengawas lebih rendah (Kompas, 24 April 2012). Rendahnya mutu guru juga terjadi di sekolah-sekolah yang dulu dikenal sebagai Rintisan Sekolah Bertaraf Internasional (RSBI). Berdasarkan data Balitbang Dikbud, bahwa kemampuan berbahasa Inggris guru Biologi, Matematika, Kimia dan Fisika yang memenuhi standar sebagai bahasa akademik dengan skor minimal 800 hanya 12,9\% dari guru RSBI, dan guru Bahasa Inggris yang memiliki skor $800 \mathrm{ke}$ atas hanya $5,6 \%$ (Suwarjo, 2013: 435).
Menghadapi keadaan tersebut, pemerintah berusaha keras untuk meningkatkan mutu guru. Berbagai kegiatan untuk meningkatkan kualitas guru telah dilakukan, misalnya melalui seminar, workshop, pelatihan, difungsikannya Musyawarah Guru Mata Pelajaran (MGMP), serta kesempatan untuk studi lanjut S2 dan S3. Undang-Undang No. 14 Tahun 2005 tentang Guru dan Dosen merupakan bukti nyata kesungguhan pemerintah untuk meningkatkan profesionalisme dan kesejahteraan guru. Berdasarkan UU No.14 Tahun 2005 tersebut jabatan guru diposisikan sebagai profesi yang bermartabat sebagai pendidik profesional. Dalam pasal 1 UU No.14 Tahun 2005, secara tegas disebutkan bahwa guru adalah pendidik profesional dengan tugas utama mendidik, mengajar, membimbing, mengarahkan, melatih, menilai dan mengevaluasi peserta didik pada pendidikan anak usia dini jalur pendidikan formal, pendidikan dasar dan pendidikan menengah. Selanjutnya, dalam pasal 4 disebutkan bahwa kedudukan guru sebagai tenaga profesional berfungsi untuk meningkatkan martabat dan peran guru sebagai agen pembelajaran berfungsi untuk meningkatkan mutu pendidikan nasional (UU No.14 Tahun 2005). Konsekuensi guru sebagai tenaga profesional, maka guru harus senantiasa meningkatkan kompetensinya dalam rangka meningkatkan mutu pembelajaran pada khususnya dan mutu pendidikan nasional pada umumnya.

Berdasarkan Undang-Undang RI Nomor 20 Tahun 2003 tentang Sistem Pendidikan Nasional, Undang-Undang No.14 Tahun 2005 tentang Guru dan Dosen, dan Peraturan Pemerintah No. 19 Tahun 2005 tentang Standar Nasional Pendidikan menegaskan bahwa guru merupakan pendidik profesional. Dengan diterapkannya UU No. 14 Tahun 2005, guru memiliki dua kedudukan, yaitu sebagai tenaga profesional dan sebagai agen pembelajaran. Sebagai tenaga profesional guru berfungsi untuk meningkatkan martabat, sebagai agen pembelajaran guru berfungsi untuk meningkatkan mutu pendidikan nasional. Guru sebagai profesional mengandung pengertian bahwa pekerjaan guru hanya dapat dilakukan oleh seseorang 
yang mempunyai kualifikasi akademik, kompetensi dan sertifikat pendidik. Kualifikasi akademik yang dipersyaratkan bagi guru adalah serendah-rendahnya berpendidikan S1 atau D4. Guru sebagai agen pembelajaran, nampak dalam perannya sebagai fasilitator, motivator, pemacu, perekayasa pembelajaran dan pemberi inspirasi belajar pada anak didiknya. Sebagai agen pembelajaran guru harus memiliki sejumlah kompetensi.

Secara sederhana kompetensi menunjuk pada orang yang memiliki kemampuan dan kecakapan. Kompetensi tidak lain merupakan performan yang mengarah kepada pencapaian tujuan secara tuntas menuju kondisi yang diinginkan. Sementara itu, dalam UU No.14 Tahun 2005, disebutkan bahwa kompetensi adalah seperangkat pengetahuan, keterampilan dan perilaku yang harus dimiliki, dihayati, dan dikuasai oleh guru atau dosen dalam melaksanakan tugas keprofesionalan. Kompetensi guru sebagai agen pembelajaran meliputi kompetensi pedagogik, kompetensi profesional, kompetensi kepribadian dan kompetensi sosial. Kompetensi pedagogik merupakan kemampuan guru dalam mengelola pembelajaran, meliputi penguasaan teori pembelajaran, kemampuan memahami peserta didik serta mampu dalam proses pembelajaran. Kompetensi profesional merupakan kemampuan guru untuk menguasai materi pelajaran secara luas dan mendalam. Kompetensi kepribadian merupakan kemampuan guru yang tercermin sebagai pribadi yang mantap, berakhlak mulia, arif dan berwibawa serta mampu menjadi teladan bagi peserta didiknya. Kompetensi sosial merupakan kemampuan guru untuk menjalin komunasi dan interaksi secara efektif terhadap peserta didik, sesama guru, orangtua dan masyarakat sekitar.

Profesionalisme guru dibuktikan dengan sertifikat pendidik yang diperoleh melalui Penilaian portofolio ataupun jalur pendidikan. Dalam menghadapi abad ke-21 ini, guru dituntut memiliki profesionalitas yang tinggi. Dalam abad ke-21, guru adalah seorang profesional di dalam masyarakat terbuka dan sebagai profesi yang kompetitif (Tilaar, 1999: 240). Adapun ciri guru yang profesional antara lain memiliki landasan pengetahuan yang kuat, berdasar atas kompetensi individual, memiliki sistem seleksi dan sertifikasi, ada kerjasama dan kompetisi yang sehat antar sejawat, adanya kesadaran profesional yang tinggi, memiliki militansi individual (Suyanto, 2007:4). Hasil penelitian yang dilakukan oleh Widoyoko (2005) terhadap 40 guru di Kabupaten Purworejo Jawa Tengah menunjukkan bahwa (1) kompetensi guru SMA di Purwarejo $17,5 \%$ berada dalam ketgori tinggi, $65 \%$ kategori cukup dan $17,5 \%$ kategori rendah; (2) pengalaman mempunyai pengaruh terhadap kompetensi, dimana guru yang mempunyai pengalaman tinggi semuanya memiliki kompetensi yang cukup dan tidak ada yang kompetensinya rendah; (3) etos kerja memberikan kontribusi positif terhadap kompetensi, dimana guru yang memiliki etos kerja tinggi memiliki kompetensi yang tinggi, sedangkan guru yang etos kerja dalam kategori cukup kompetensinya relatif rendah (Widoyoko, 2005:374-380).

Guru profesional dituntut untuk selalu mengembangkan diri dalam rangka mempertahankan dan meningkatkan profesionalismenya. Permeneg PAN \& RB No.16 Tahun 2009 tentang Pengembangan Keprofesian Berkelanjutan (PKB), menyebutkan bahwa guru wajib melaksanakan kegiatan Pengembangan Keprofesian Berkelanjutan (PKB) yang terdiri atas pengembangan diri, publikasi ilmiah dan karya inovatif. Pengembangan diri dapat dilakukan melalui studi lanjut (S2/S3), mengikuti seminar, workshop dan kegiatan MGMP. Kegiatan publikasi ilmiah antara lain presentasi dalam forum ilmiah, publikasi ilmiah hasil penelitian khususnya Penelitiaan Tindakan Kelas (PTK), publikasi buku pelajaran, buku pengayaan dan pedoman guru. Kegiatan karya inovatif antara lain: menemukan teknologi tepat guna, menciptakan karya seni, membuat alat peraga/praktikum dan mengikuti pengembangan penyusunan standar pedoman maupun soal. PKB dilaksanakan dalam upaya mewujudkan guru yang profesional, bermantabat dan sejahtera sehingga mampu mewujudkan tujuan pendidikan nasional. Salah satu kegiatan pengembangan profesi yang dilakukan guru adalah melaksanakan 
Penelitian Tindakan kelas (PTK). Permasalahan yang ada adalah bagaimana tingkat kompetensi guru SMP dalam penelitian tindakan kelas?

PTK merupakan penelitian yang dilakukan guru di kelas dengan tujuan untuk memperbaiki dan menyempurnakan proses dan praksis pembelajaran. Kelas sebagai unit terkecil dalam proses pembelajaran, dapat digunakan sebagai titik tolak guru untuk mendalami secara kritis terhadap apa yang dilakukan guru maupun siswa selama pembelajaran. Oleh sebab itu, guru dapat menentukan sendiri tindakan untuk memperbaiki strategi pembelajarannya secara terus menerus sehingga mutu pembelajarannya semakin meningkat. Sehubungan dengan itu, Suyadi (2011:18) berpendapat bahwa PTK merupakan pencermatan dalam bentuk tindakan terhadap kegiatan belajar yang sengaja dimunculkan dan terjadi dalam sebuah kelas secara bersamaan. Perlunya PTK didasarkan adanya kesadaran guru bahwa ada permasalahan pembelajaran yang mendesak untuk segera diperbaiki melalui suatu tindakan dalam rangka perbaikan kualitas proses belajar mengajar.

Di lain pihak PTK merupakan upaya kolaboratif antara guru dan siswa sebagai satuan kerjasama dengan perspektif yang berbeda, bagi guru dimaksudkan untuk meningkatkan mutu profesionalnya dan bagi siswa dimaksudkan untuk meningkatkan prestasi belajarnya. PTK bersifat self-evaluatif, yaitu kegiatan modifikasi praksis yang dilakukan secara kontinyu, dievaluasi dalam situasi yang terus berjalan dengan tujuan untuk meningkatkan perbaikan dan praktek nyata. PTK dapat dipandang sebagai salah satu cara yang strategis dalam memperbaiki dan meningkatkan layanan pendidikan, meningkatkan kualitas program sekolah secara keseluruhan dalam masyarakat yang cepat berubah. Tim Pelatih UNY (2000:5) berpendapat bahwa tujuan yang ingin dicapai dengan adanya PTK adalah meningkatkan praktek pembelajaran secara berkesinambungan; mengembangkan kemampuan guru untuk menghadapi permasalahan aktual pembelajaran di kelasnya dan menumbuhkan budaya meneliti di kalangan guru atau pendidik
Kemmis \& Taggart (1988:31) menyatakan bahwa pelaksanaan penelitian tindakan mencakup empat langkah, yaitu: merumuskan masalah dan merencanakan tindakan; melaksanakan tindakan dan pengamatan dan monitoring; refleksi hasil pengamatan dan perubahan/revisi perencanaan untuk pengembangan selanjutnya. Tahapan dalam penelitian tindakan sebagai tahapan spiral, dimana setiap spiral memiliki planning, action dan evaluasi pada setiap akhir tindakan sehingga yang harus dilakukan penelitian tindakan adalah: to develop a plan of action to improve what is already happening; to act to implement the plan; to observe the effect of action in the context in which it occurs; and to reflect on these effects as a basis for futher planning (Kemmis \& Taggart, 1988: 7). Hal senada dikatakan oleh Asmani bahwa PTK merupakan penelitian melalui proses pengkajian bersiklus yang terdiri atas empat tahapan, yaitu planning, action, observation dan reflection (Asmani, 2011:25).

\section{METODE}

Penelitian ini merupakan penelitian survei dan dimaksudkan untuk memotret kompetensi guru SMP DIY terhadap PTK. Populasi penelitian ini adalah guru-guru SMP di Daerah Istimewa Yogyakarta. Untuk menentukan sampel digunakan purposive sampling, yaitu guruguru yang mengikuti kegiatan IHT sosialisasi Kurikulum 2013 yang dilaksanakan oleh Direktorat Pendidikan Dasar Depdikbud. Sampel diambil secara purposif karena lebih cocok digunakan untuk penelitian kualtatif dan penelitian yang tidak melakukan generalisasi (Sugiyono, 2010:124). Responden dari SMP Daerah Istimewa Yogyakarta dari Kabupaten Gunung Kidul: yaitu guru SMPN 1 Tanjungsari; SMPN 1 Purwasari; SMPN1 Gedangsari, SMPN 2 Karangmojo; SMPN 2 Nglipar; SMP PGRI Semanu, dan Kabupaten Sleman yaitu SMPN 2 Ngemplak dan SMP Muhammadiyah Mlati, yang semuanya berjumlah 55 orang.

Pengumpulan data digunakan kuesioner dan dokumentasi. Instrumen penelitian disusun berdasarkan aspek tingkat pengetahuan teoretik, tingkat kemampuan kognitif, tingkat kemampu- 
an teknis, dan pengalaman. Dari hasil uji coba diketahui bahwa instrumen tersebut valid, karena hasil perhitungan diperoleh koefisien validitasnya 0,30 atau lebih. Sementara itu, uji relibalitas dengan menggunakan Alpha Cronbach diperoleh hasil sebagai berikut koefisien alpha untuk aspek (1) tingkat pengetahuan teoretik sebesar 0,897 ; (2) tingkat kemampuan kognitif sebesar 0,885; (3) tingkat kemampuan teknis sebesar 0.840; dan (4) pengalaman sebesar 0,818 . Berdasarkn hasil uji coba tersebut diketahui bahwa instrumen yang akan digunakan untuk mendekti tingkat kompetensi PTK valid dan reliabel, maka instrumen tersebut layak atau telah memenuhi persyaratan uji validitas dan reliabilitas untuk digunakan dalam penelitian ini. Analisis data untuk mengetahui perbedaan tingkat kompetensi PTK guru digunakan T-test.

\section{HASIL DAN PEMBAHASAN}

\section{Hasil}

Berdasarkan data yang dikumpulkan diketahui bahwa 54,5\% guru laki-laki dan $45,5 \%$ perempuan, $96 \%$ berpendidikan S1 dan hanya $4 \%$ yang berpendidikan S2. Dilihat dari segi umur dan masa kerja, data responden disajikan dalam Tabel 1.

Sebagian besar guru SMP di DIY berumur antara 31- 50 tahun, dengan masa kerja antara $6-20$ tahun. Selanjutnya, jika ditinjau dari segi masa kerja dan golongan kepangkatan, dapat dilihat dalam Tabel 2.

Guru golongan IIIa dan IIIb dikelompokkan sebagai guru yunior dan golongan IVa dan $\mathrm{IVb}$ sebagai guru senior, maka dapat diketahui bahwa perbandingan antara guru yunior dengan guru senior ternyata berimbang, yaitu guru yunior $41 \%$, guru senior $45 \%$ dan selebihnya guru golongan IIIc dan IIId.

Selanjutnya, bagaimana hubungan antara umur dengan kepangkatan/golongan, apakah guru yang memiliki umur yang panjang memiliki kepangkatan/golongan yang tinggi atau sebaliknya, disajikan dalam Tabel 3.

Tabel 1. Keadaan Guru SMP DI DIY Berdasarkan Umur dan Masa Kerja

\begin{tabular}{|c|c|c|c|c|c|c|c|c|c|}
\hline \multirow{2}{*}{$\begin{array}{l}\text { Umur } \\
\text { (th) }\end{array}$} & \multicolumn{7}{|c|}{ Masa kerja (tahun) } & \multirow[t]{2}{*}{ Total } & \multirow[t]{2}{*}{ Persen } \\
\hline & $1-5$ & $6-10$ & $11-15$ & $16-20$ & $21-25$ & $26-30$ & $31-35$ & & \\
\hline $20-25$ & 1 & 0 & 0 & 0 & 0 & 0 & 0 & 1 & 1.81 \\
\hline $26-30$ & 2 & 2 & 0 & 0 & 0 & 0 & 0 & 4 & 7.27 \\
\hline $31-35$ & 1 & 2 & 0 & 0 & 0 & 0 & 0 & 3 & 5.45 \\
\hline $36-40$ & 1 & 8 & 1 & 0 & 0 & 0 & 0 & 10 & 18.18 \\
\hline $41-45$ & 0 & 4 & 6 & 7 & 0 & 0 & 0 & 17 & 30.91 \\
\hline $46-50$ & 0 & 0 & 1 & 6 & 2 & 2 & 0 & 11 & 20.00 \\
\hline $51-55$ & 0 & 0 & 0 & 1 & 0 & 2 & 1 & 4 & 7.27 \\
\hline $56-60$ & 0 & 0 & 0 & 1 & 2 & 2 & 0 & 5 & 9.10 \\
\hline Total & 5 & 16 & 8 & 15 & 4 & 6 & 1 & 55 & \\
\hline$\%$ & 9.09 & 29.09 & 14.55 & 27.27 & 7.27 & 10.91 & 1.81 & & 100 \\
\hline
\end{tabular}

Tabel 2. Keadaan Guru SMP DIY Berdasarkan Masa Kerja dan Golongan

\begin{tabular}{ccccccccr}
\hline \multirow{2}{*}{ Masa kerja } & \multicolumn{9}{c}{ Golongan } & \multirow{2}{*}{ Total } & Persen \\
\cline { 2 - 6 } & IIIa & IIIb & IIIc & IIId & IVa & IVb & & \\
\hline 1 - 5 tahun & 5 & 0 & 0 & 0 & 0 & 0 & 5 & 9.09 \\
6 - 10 tahun & 8 & 8 & 0 & 0 & 0 & 0 & 16 & 29.09 \\
11 - 15 tahun & 1 & 1 & 0 & 3 & 2 & 1 & 8 & 14.55 \\
16 - 20 tahun & 0 & 0 & 2 & 2 & 11 & 0 & 15 & 27.27 \\
21 - 25 tahun & 0 & 0 & 0 & 0 & 4 & 0 & 4 & 7.27 \\
26 - 30 tahun & 0 & 0 & 0 & 0 & 6 & 0 & 6 & 10.91 \\
31 - 35 tahun & 0 & 0 & 0 & 0 & 1 & 0 & 1 & 1.81 \\
\hline Total & 14 & 9 & 2 & 5 & 24 & 1 & 55 & \\
Persen & 25.45 & 16.36 & 3.64 & 9.09 & 43.64 & 1.81 & & 100.00 \\
\hline
\end{tabular}


Tabel 3. Hubungan Umur dengan Kepangkatan/Golongan Guru

\begin{tabular}{rrrrrrrrr}
\hline \multirow{2}{*}{ Umur } & \multicolumn{9}{c}{ Golongan } & Jumlah & Persen \\
\cline { 2 - 6 } & III a & III b & III c & III d & IV a & IV b & & \\
\hline $20-25$ tahun & 1 & 0 & 0 & 0 & 0 & 0 & 1 & 1.81 \\
$26-30$ tahun & 3 & 1 & 0 & 0 & 0 & 0 & 4 & 7.27 \\
$31-35$ tahun & 1 & 2 & 0 & 0 & 0 & 0 & 3 & 5.45 \\
$36-40$ tahun & 6 & 3 & 0 & 1 & 0 & 0 & 10 & 18.18 \\
$41-45$ tahun & 2 & 3 & 2 & 3 & 6 & 1 & 17 & 30.91 \\
$46-50$ tahun & 1 & 0 & 0 & 1 & 9 & 0 & 11 & 20.00 \\
$51-55$ tahun & 0 & 0 & 0 & 0 & 4 & 0 & 4 & 7.27 \\
$56-60$ tahun & 0 & 0 & 0 & 0 & 5 & 0 & 5 & 9.09 \\
\hline Jumlah & 14 & 9 & 2 & 5 & 24 & 1 & 55 & \\
Persen & 25.45 & 16.36 & 3.63 & 9.09 & 43.64 & 1.81 & & 100 \\
\hline
\end{tabular}

Tabel 4. Hubungan Kepangkatan /Golongan Guru dengan Pengalaman PTK

\begin{tabular}{rcccr}
\hline Golongan & \multicolumn{2}{c}{ Pernah PTK } & Jumlah & \multicolumn{1}{c}{ Persen } \\
\cline { 2 - 5 } & Belum Pernah & Pernah PTK & 14 & 25.45 \\
\hline Golongan III a & 12 & 2 & 9 & 16.36 \\
Golongan III b & 8 & 1 & 2 & 3.63 \\
Golongan III c & 1 & 1 & 5 & 9.09 \\
Golongan III d & 2 & 3 & 24 & 43.64 \\
Golongan IV a & 9 & 15 & 1 & 1.81 \\
Golongan IV b & 0 & 1 & 55 & 100 \\
Jumlah & 32 & 23 & & \\
Persen & 58.19 & 41.81 & & \\
\hline
\end{tabular}

Tabel 5. Hubungan Jenjang Pendidikan dan PTK Guru SMP DIY

\begin{tabular}{lcccr}
\hline \multirow{2}{*}{ Pendidikan } & \multicolumn{2}{c}{ Pernah Melakukan PTK } & \multirow{2}{*}{ Jumlah } & \multirow{2}{*}{ Persen } \\
\cline { 2 - 3 } Pendidikan S 1 & Belum Pernah & Pernah & & \\
\cline { 2 - 4 } Pendidikan S 2 & 32 & 21 & 53 & 96.36 \\
\hline Jumlah & 0 & 2 & 2 & 3.64 \\
\hline
\end{tabular}

Ditinjau dari segi umur, diketahui bahwa sebanyak $38(69 \%)$ orang guru berumur antara $36-50$ tahun, sebanyak 8 orang (15\%) berumur antara 20-35 tahun dan 9 orang (16\%) berumur 51-60 tahun. Ditinjau dari kepangkatan/golongan, 55\% guru yang memiliki kepangkatan/golongan III dan $45 \%$ guru golongan IV.

Sebanyak 32 orang (58\%) belum pernah melakukan PTK dan hanya 23 orang (42\%) pernah PTK. Jika dikaitkan dengan kepangkatan/golongan, terdapat 16 orang (29\%) guru golongan IV pernah melakukan PTK, sedangkan untuk guru golongan III yang pernah melakukan PTK hanya 7 orang (13\%).
Jumlah guru yang berpendidikan S1 sebanyak $96 \%$ orang dan hanya $4 \%$ yang berpendidikan S2. Secara keseluruhan terdapat $41 \%$ guru yang pernah PTK dan $58 \%$ belum pernah PTK. Guru yang berpendidikan S1 yang pernah melakukan PTK sebanyak 21 orang (40\%), sedangkan guru yang berpendidikan S2 semuanya pernah melakukan PTK.

Untuk mengukur tingkat kompetensi PTK, digunakan 60 butir pernyataan sebagai penjabaran dari 6 komponen, yaitu komponen : tingkat penguasaan teoretis, tingkat kemampuan kognitif, kemampuan teknis, pengalaman, tingkat kesulitan dan faktor pendukung. Butir-butir pernyataan disusun menggunakan model skala 
Likert dengan 4 alternatif jawaban. Adapun hasil yang diperoleh disajikan dalam Tabel 6 . Selanjutnya, untuk mengetahui perbedaan tingkat kompetensi dilihat dari karakteristik masing-masing responden, dilakukan uji t dengan hasil yang ditunjukkan pada Tabel 7 .

Guru yang memiliki pangkat/golongan III, jabatan fungsionalnya adalah Guru Pratama dan kelompok Guru Muda, dengan pangkat tertinggi sebagai Penata Tingkat I, sedangkan guru yang memiliki pangkat/golongan IVa, IVb dan IVc, jabatan fungsionalnya termasuk kelompok Guru Madya, dan pangkat tertinggi adalah Pembina Tk.I. Berdasarkan uji t yang disajikan dalam tabel 7 , ternyata nilai $t$ untuk semua komponen kompetensi PTK tidak signifikan ( $p$ >0.05). Hal ini berarti tingkat penguasaan teoretis, kemampuan kognitif, kemampuan teknis dan pengalaman guru golongan III dengan IV tidak berbeda. Dengan kata lain, tidak ada perbedaan tingkat kompetensi PTK antara guru golongan III dan IV.

Ditinjau dari masa kerja, diketahui masa kerja terendah guru SMP di DIY terendah satu tahun dan tertinggi 32 tahun. Selanjutnya untuk mengetahui ada tidaknya perbedaan masa kerja terhadap kompetensi PTK, masa kerja dikelompokkan menjadi dua kelompok masa kerja, yaitu kurang dari 15 tahun dan lebih dari 15 tahun. Hasil uji t perbedaan masa kerja terhadap tingkat kompetensi PTK guru disajikan dalam Tabel 8.

Uji t menunjukkan bahwa tidak ada perbedaan penguasaan teoretis, kemampuan kognitif, kemampuan teknis yang disebabkan oleh masa kerja. Hal ini ditunjukkan oleh nilai t yang tidak signifikan $(\mathrm{p}>0.05)$. pada komponen pengalaman memiliki nilai $\mathrm{t}$ yang signifikan $(\mathrm{P}<0.05)$, yang berarti terdapat perbedaan yang signifikan. Dengan demikian, guru yang memiliki masa kerja lebih dari 15 tahun memiliki pengalaman yang lebih dibandingkan guru yang masa kerjanya kurang dari 15 tahun. Selanjutnya, untuk mengetahui ada tidaknya perbedaan tingkat kompetensi PTK antara guru yang pernah melakukan PTK dengan yang belum pernah, disajikan dalam Tabel 9.

Tabel 6. Tingkat Kompetensi PTK Guru SMP di DIY

\begin{tabular}{llccc}
\hline No. & Aspek & \multicolumn{3}{c}{ Kategori } \\
\cline { 3 - 5 } & & Tinggi & Sedang & Rendah \\
\hline 1. & Tingkat Penguasaan Teoretik & $13 \%$ & $87 \%$ & 0 \\
2. & Tingkat Kemampuan Kognitif & 0 & $100 \%$ & 0 \\
3. & Tingkat Kemampuan Teknis & 0 & $86 \%$ & $14 \%$ \\
4. & Pengalaman & $25 \%$ & $75 \%$ & 0 \\
5. & Tingkat Kesulitan & $37 \%$ & $63 \%$ & 0 \\
6. & Faktor Pendukung & $64 \%$ & $36 \%$ & 0 \\
\hline
\end{tabular}

Tabel 7. Perbedaan Tingkat Kompetensi PTK Guru SMP di DIY Dilihat dari Aspek Kepangkatan

\begin{tabular}{llllll}
\hline \multirow{2}{*}{ Komponen } & \multicolumn{2}{l}{$\begin{array}{l}\text { Levene's Test for Equality of } \\
\text { variances }\end{array}$} & \multicolumn{2}{l}{$\begin{array}{l}\text { t-test for Equality of } \\
\text { Geans }\end{array}$} \\
\cline { 2 - 5 } Kelongan/ & F & Sig. & t & df \\
\hline Penguasaan Teoretis & Gol. III & 0.053 & 0.819 & -2.125 & 53 \\
& Gol. IV & & & -2.109 & 49.43 \\
Kemampuan Kognitif & Gol. III & 0.001 & 0.976 & -1.655 & 53 \\
& Gol. IV & & & -1.646 & 50.04 \\
Kemampuan Teknis & Gol. III & 0464 & 0.499 & -1.559 & 53 \\
\multirow{2}{*}{ Pengalaman } & Gol. IV & & & -1.537 & 47.67 \\
& Gol. III & 0.160 & 0.691 & -.502 & 53 \\
& Gol. IV & & & -.504 & 51.78 \\
\hline
\end{tabular}


Tabel 8. Perbedaan Tingkat Kompetensi PTK Guru SMP di DIY Dilihat dari Aspek Masa Kerja sebagai Guru

\begin{tabular}{|c|c|c|c|c|c|}
\hline \multirow[t]{2}{*}{ Komponen } & \multirow[t]{2}{*}{ Masa Kerja } & \multicolumn{2}{|c|}{$\begin{array}{l}\text { Levene's Test for Equality } \\
\text { of variances }\end{array}$} & \multicolumn{2}{|c|}{$\begin{array}{l}\text { t-test for Equality of } \\
\text { Means }\end{array}$} \\
\hline & & $\mathrm{F}$ & Sig. & $\mathrm{t}$ & $\mathrm{df}$ \\
\hline \multirow[t]{2}{*}{ Penguasaan teoretis } & Kurang dari 15 th & 0.549 & 0.501 & -1.553 & 53 \\
\hline & Lebih dari 15 th & & & -1.572 & 52.39 \\
\hline \multirow[t]{2}{*}{ Kemampuan Kognitif } & Kurang dari 15 th & 0.174 & 0.678 & -1.597 & 53 \\
\hline & Lebih dari 15 th & & & -1.593 & 51.86 \\
\hline \multirow[t]{2}{*}{ Kemampuan Teknis } & Kurang dari 15 th & 0.070 & 0.793 & -1.287 & 53 \\
\hline & Lebih dari 15 th & & & -1.287 & 52.30 \\
\hline \multirow[t]{2}{*}{ Pengalaman } & Kurang dari 15 th & 4.093 & 0.045 & -1.867 & 53 \\
\hline & Lebih dari 15 th & & & -1.840 & 46.71 \\
\hline
\end{tabular}

Tabel 9. Perbedaan Tingkat Kompetensi PTYK Guru di DIY Dilihat dari Aspek Pengalaman Melakukan PTK

\begin{tabular}{llllll}
\hline \multirow{2}{*}{ Komponen } & Pernah PTK & \multicolumn{2}{l}{$\begin{array}{l}\text { Levene's Test for Equality } \\
\text { of variances }\end{array}$} & \multicolumn{2}{l}{$\begin{array}{l}\text { t-test for Equality of } \\
\text { Means }\end{array}$} \\
\cline { 3 - 6 } & & F & Sig. & t & df \\
\hline Penguasaan teoretis & Belum Pernah & 3.420 & 0.07 & -4.445 & 53 \\
& Pernah & & & -4.710 & 52.967 \\
Kemampuan Kognitif & Belum Pernah & 5.044 & 0.029 & -2.105 & 53 \\
& Pernah & & & -2.260 & 50.04 \\
Kemampuan Teknis & Belum Pernah & 0.599 & 0.442 & -3.043 & 53 \\
& Pernah & & & -3.199 & 52.965 \\
Pengalaman & Belum Pernah & \multirow{2}{*}{8.645} & 0.005 & -2.319 & 53 \\
& Pernah & & & -2.483 & 52.54 \\
\hline
\end{tabular}

Hasil uji t antara pernah tidaknya melakukan PTK terhadap komponen PTK yang berupa penguasaan kognitif, dan pengalaman memiliki nilai $\mathrm{t}$ yang signifikan $(\mathrm{p}<0.05)$, sedangkan untuk komponen penguasaan teoretis dan kemampuan teknis memiliki nilai $\mathrm{t}$ yang tidak signifikan ( $p>0.05)$. Dengan demikian, dapat disimpulkan bahwa guru yang pernah melakukan PTK memiliki kemampuan kognitif dan pengalaman yang berbeda dibandingkan guru yang belum pernah melakukan PTK.

\section{Pembahasan}

Data menunukkan bahwa terdapat 14 guru yang masih menduduki golongan IIIa, dan sebanyak 64\% atau sebanyak 9 guru golongan IIIa yang telah berumur $36-50$ tahun. Jika digunakan asumsi mereka diangkat menjadi guru pada umur 25 tahun, berarti mereka ini sudah 10-15 tahun tidak naik pangkat, karena hingga umur 36-40 tahun, bahkan ada seorang guru yang telah berumur 46-50 tahun, mereka masih tetap berada pada golongan III a. Jika setiap 4 tahun guru dapat naik pangkat/golongan, maka kesembilan guru ini seharusnya mereka sudah berada dalam golongan III d. Berdasarkan hasil wawancara diketahui bahwa salah satu faktor penyebab guru umur 36-50 tahun ini belum naik pangkat disebabkan mereka tidak memiliki kegiatan pengembangan profesi yang salah satunya berupa hasil laporan PTK.

Dengan kata lain, tingkat kompetensi PTK yang dimiliki masih relatif rendah. Keadaan demikian, perlu mendapatkan perhatian dari kepala sekolah maupun pemerintah daerah untuk memberikan arahan, bimbingan, fasilitas dan kalau perlu sanksi, misalnya ancaman dipindahkan dari status guru menjadi tenaga administrasi, atau diturunkan kepangkatannya kepada guru yang tidak naik pangkat selama 10 tahun atau lebih tidak naik pangkat. Namun, hal yang menggembirakan ternyata ada satu 
guru yang baru berumur antara 41-45 tahun telah mencapai golongan IV b. Dari hasil wawancara, diketahui bahwa guru memiliki motivasi yang tinggi, berpendidikan S2, banyak melakukan penelitian dan memiliki semangat yang kuat untuk selalu mengejar prestasi dan terbukti yang bersangkutan pernah mendapatkan predikat guru teladan nasional. Berkat prestasi yang telah dicapai, yang bersangkutan kini selalu dilibatkan dalam pengembangan kurikulum pada tingkat nasional. Ini dapat dijadikan teladan bahwa seorang guru SMP berkat ketekunan dan semangat tinggi akhirnya mampu berkiprah secara nasional untuk ikut membangun dan mengembangkan pendidikan nasional.

Jika dilihat dari pernah tidaknya guru melakukan PTK, diketahui bahwa dari 30 guru golongan III, hanya 7 orang (23\%) yang pernah melakukan PTK, dimana guru golongan IIIa dan IIId lebih banyak melakukan PTK dibandingkan guru golongan IIIb dan IIIc. Sementara itu, dari 25 guru golongan IV yang pernah melakukan PTK sebanyak 16 orang (64\%), dengan rincian golongan IVa sebanyak 15 orang dan satu guru golongan IV b satu orang. Banyaknya guru golongan IVa melakukan PTK, disebabkan sebelum terbitnya Permeneg PAN \& RB No.16 tahun 2009, guru yang akan naik ke golongan IVa dipersyaratkan memiliki karya pengembangan profesi berupa hasil penelitian. Sementara itu, setelah diterbitkannya Permeneg PAN \& RB No.16 Tahun 2009, kenaikan pangkat mulai ke III $b$ dan seterusnya dipersyaratkan memiliki karya pengembangan profesi.

Guru yang memiliki kepangkatan/golongan III dengan golongan IV terhadap tingkat kompetensi PTK guru ternyata tidak signifikat ( $\mathrm{p}>0.05$ ), yang berarti tidak ada perbedaan tingkat kompetensi PTK guru antara guru golongan III dengan guru golongan IV baik yang berkaitan dengan penguasaan teoretis, kemampuan kognitif, kemampuan teknis maupun pengalaman dalam penelitian yang lain. Dengan kata lain guru golongan III memiliki kemampuan PTK yang relatif sama dengan guru golongan IV. Seharusnya guru golongan IV yang memiliki jabatan sebagai Guru Pembina, Guru Madya diharapkan memiliki tingkat kompetensi yang lebih tinggi dibanding dengan Guru Peata, Guru Muda. Berdasarkan data pada Tabel 4 ternyata tidak ada perbedaan tingkat kompetensi PTK antara guru golongan III dengan golongan IV, baik dalam penguasaan teoretis, kemampuan kognitif, kemampuan teknis maupun pengalaman. Temuan ini memperkuat temuan hasil penelitian tentang "Pembinaan Guru Dengan Sisuem Kredit”yang dilakukan oleh Sugiyono (2002:131) yang menyimpulkan bahwa tidak terdapat hubungan positif antara jenjang jabatan fungsional dengan kemampuan kerja guru, guru golongan III memiliki kinerja yaang sama dengan guru golongan IV .

Berdasarkan hasil uji tingkat kompetensi PTK guru dilihat dari aspek masa kerja maupun pernah melakukan PTK, diketahui bahwa tidak ada perbedaan tingkat penguasaan teoretis, kemampuan kognitif, dan kemampuan teknis terhadap tingkat kompetensi PTK guru dengan $\mathrm{t}$ hitung yang tidak signifikan ( $p>0.05$ ), sedangkan uji untuk komponen pengalaman melakukan penelitian diperoleh $\mathrm{p}<0.05$. Demikian data pada Tabel 6 menunjukkan bahwa pengalaman melakukan penelitian dan kemampuan kognitif memiliki perbedaan siginfikan terhadap tingkat kompetensi PTK guru, ditunjukkan oleh $p<0.05$. Dengan kata lain, adanya pengalaman melakukan penelitian mempengaruhi perbedaan tingkat kompetensi PTK guru. Temuan ini sejalan dengan hasil penelitian tentang 'Kompetensi Mengajar Guru Ekonomi SMA Kabupaten Purworejo" yang menyimpulkan bahwa pengalaman memiliki sumbangan yang signifikan terhadap kompetensi guru, dimana guru yang rendah pengalamannya memiliki kompetensi dalam kategori kurang (Widoyoko, 2005: 379-380).

Dalam rangka mempertahankan dan meningkatkan profesionalitas guru, pemerintah mewajibkan kepada setiap guru yang telah memperoleh sertifikasi untuk mengembangkan profesinya secara berkelanjutan. Hal ini tertuang dalam Permeneg PAN \& RB No.16 Tahun 2009 tentang Pengembangan Keprofesian Berkelanjutan (PKB), disebutkan bahwa guru wajib melaksanakan kegiatan Pengembangan Keprofesian Berkelanjutan. Bahkan, dalam Permeneg 
PAN \& RB tersebut, guru yang akan naik pangkat ke golongan IIIb diwajibkan memiliki karya pengembangan profesi, misalnya karya Penelitian Tindakan Kelas (PTK). Namun, meskipun telah ada peraturan yang mewajibkan guru untuk mengembangkan profesi melalui PTK, kenyataan di lapangan masih banyak guru yang belum melaksanakan PTK. Dari hasil penelitian diketahui bahwa 16 guru (29\%) menyatakan masih menghadapi banyak kendala untuk melaksanakan PTK, baik kendala internal (misalnya dalam menemukan masalah, mengolah data serta tiadanya pendamping atau pembimbing PTK). Kondisi ini sejalan dengan hasil penelitian tentang "Sikap Guru DIY terhadap Pengembangan Profesi" yang menyimpulkan bahwa 58\% guru memiliki tingkat pemahaman terhadap pengembangan profesi rendah, dan $8 \%$ guru memiliki kesulitan pengembangan profesi dalam kategori tinggi.

Padatnya jadwal mengajar dan tugas administrasi lainnya dipandang sebagai alasan utama mengapa para guru tidak melaksanakan PTK. Para guru menyatakan merasa sulit menyisihkan sebagian waktu untuk melaksanakan PTK, sebab dalam satu minggu banyak guru yang mengajar hingga 30 jam tatap muka. Untuk keperluan mengajar, guru masih harus mempersiapkandan menyusun Rencana Pelaksanaan Pembelajaran, membuat soal serta mengoreksi tugas. Kondisi ini sesuai dengan hasil penelitian Badrun (2011:470), yaitu bahwa $82,5 \%$ guru belum melakukan penelitian, disebabkan adanya kesibukan kegiatan sekolah serta belum terbiasa menulis dan meneliti. Namun demikian, guru lebih tertarik untuk mengikuti seminar baik dengan biaya sendiri ataupun biaya dari sekolah. Hasil penelitian yang dilakukan oleh Khotijah (2013:96) tentang "Kinerja Guru Madrasah dan Guru Pendidikan Agama Islam Pasca Sertifikat di Sumatera Selatan" memperkuat kondisi kinera guru, bahwa $75 \%$ guru memiliki kinerja dalam pengembangan progfesi berada dalam kategori sedang dan $10 \%$ guru berada dalam kategori rendah.

Di lain pihak, ada beberapa guru yang telah beberapa kali melakukan PTK, namun tetap saja menghadapi kendala, antara lain: (1) kesulitan untuk sinkronisasi waktu antara peneliti dengan kolaborator, mengingat jadwal mengajar berbeda antar guru bidang studi serumpun; (2) kesulitan saat hasil PTK tersebut akan digunakan untuk naik pangkat, yaitu laporan PTK belum dapat diterima oleh Tim Penilai Angka Kredit; (3) kesulitan belum dipahaminya gaya selingkung penulisan artikel yang diharapkan oleh Tim Penilai angka kredit.

\section{PENUTUP}

Berdasarkan pembahasan hasil penelitian tersebut, dapatlah disimpulkan antara lai, bahwa guru SMP di DIY: (1) memiliki tingkat kompetensi PTK dalam kategori sedang khususnya tingkat penguasaan teoretik, kemampuan kognitif dan kemampuan teknis; (2) tidak ada perbedaan tingkat kompetensi PTK antara guru golongan III dengan golongan IV; (3) guru yang pernah melakukan PTK memiliki kemampuan kognitif dan pengalaman yang berbeda dibandingkan guru yang belum pernah melakukan PTK; (4) tidak ada perbedaan penguasaan teoretis, kemampuan kognitif, kemampuan teknis yang disebabkan oleh masa kerja; (5) kesibukan dan kurangnya kesempatan merupakan faktor penyebab guru tidak melakukan guru penelitian; dan (6) masih terjadi laporan penelitian PTK tidak dapat digunakan untuk naik pangkat karena adanya perbedaan gaya selingkung laporan.

\section{UCAPAN TERIMA KASIH}

Pada kesempatan ini saya mengucapkan terimakasih kepadaberbagai pihak atas bantuannya dalam penelitian ini. Pertama, terima kasih kepada Direktur Direktorat Pendidikan Dasar dan Menengah Depdikbud yang telah menugaskan saya untuk melakukan sosialisasi Kurikulum 2013 dalam program Pemdampingan IHT pada SMP Potensial di DIY. Kedua, terima kasih saya sampaikan kepada redaksi, staf dan mitra bestari Jurnal Cakrawala Pendidikan yang telah memberikan masukan dan bimbingan dalam penulisan artikel ini. Semoga amal beliau diberikan pahala yang berlipat ganda oleh Allah SWT. Amin. 


\section{DAFTAR PUSTAKA}

Asmani, Jamar Ma'mur. 2011. Tips Pintar PTK: Penelitian Tindakan Kelas. Yogyakarta: Penerbit Laksana.

Badrun, K. 2011. "Kinerja Guru Profesional (Guru Pasca Sertifikasi). Cakrawala Pendidikan, Jurnal Ilmiah Pendidikan. Th. XXX, No. 3.

Kemmis, Stephen \& Taggart, Robin. 1982. The Action Research Planner. Victoria: Deakin University.

Khotijah, Nyayu. 2013. "Kinerja Guru Madrasah dan Guru Pendidikan Agama Islam Pasca Sertifikasi di Sumatera Selatan". Cakrawala Pendidikan, Jurnal Ilmiah Pendidikan, Th XXXII, No. 1.

Kompas, Harian Umum. 2012. Kualitas Guru Masih Rendah, Rabu, 7 Maret.

Kompas, Harian Umum. 2012. Perbaikan Kompetensi Guru Jadi Prioritas. Selasa, 4 April.

Sugiyono. 2010. Metode Penelitian Pendidikan, Pendekatan Kuantitatif, Kualitatif dan $R \& D$. Bandung: Alfabeta.

Sugiyono. 2002. "Pembinaan Guru dengan Sistem Kredit". Cakrawala Pendidikan, Th XXI, No.1.
Suwarjo. 2013. Pendidikan untuk Pencerah dan Kemandirian Bangsa: Kualitas Pendidik (Guru) Indonesia. Yogyakarta: AshShaft.

Suyadi. 2011. Panduan Penelitian Tindakan Kelas. Buku Panduan Wajib bagi Para Pendidik. Yogyakarta: DIVA Press.

Suyanto. 2007. Tantangan Profesional Guru di Era Global. Pidato Dies Natalis ke-43 Universitas Negeri Yogyakarta, 21 Mei 2007.

Tilaar, H.A.R. 1999. Beberapa Agenda Reformasi Pendidikan Nasional: dalam Perspektif Abad 21. Magelang: Indonesia Tera.

Tim Pelatih Penelitian UNY.2000. Penelitian Tindakan (Action Research). Makalah Pelatihan Penelitian Tindakan (Action Research) dalam Rangka Pelatihan Guru SLTP. Diselenggarakan atas kerjasma Direktorat Pendidikan Menengah Umum dengan Lembaga Penelitian UNY.

Widoyoko, Eko Putra. 2005. "Kometensi Mengajar Guru Ekonomi SMA Kabupaten Purworejo". Cakrawala Pendidikan, Jurnah Ilmiah Pendidikan. Tahun XXIV. No. 3. 